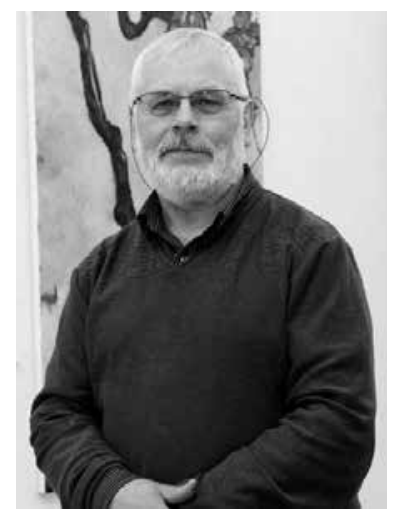

Tapyba
Painting

https://doi.org/10.24101/logos.2020.52

Gauta 20200710

\title{
JONAS DANILIAUSKAS
}

\section{TAPYTOJAS JONAS DANILIAUSKAS}

Gimè 1950 m. Lekéčiuose Šakių rajone, mokèsi M. K. Čiurlionio meno mokykloje. 1974 m. baigè Valstybinį dailès institutą, kur studijavo tapybą vadovaujamas A. Petrulio ir J. Švažo (pastarasis buvo diplominio darbo vadovas). 1974-1984 m. dèstė M. K. Čiurlionio meno mokykloje, vèliau VDI Tapybos katedroje. Surengè daugybę personalinių parodų ịvairiuose Lietuvos miestuose, taip pat Badene, Ciuriche, Greifsvalde, Londone, Varšuvoje, Poznanejje ir kitur. Dalyvavo grupinėse parodose Bulgarijoje, Danijoje, Rusijoje, Suomijoje, JAV, VDR, VFR, Lenkijoje, Latvijoje, Gruzijoje, Turkijoje, Armėnijoje, Japonijoje, Ispanijoje, Indijoje, Didžiojoje Britanijoje, Prancūzijoje, Šveicarijoje, Turkijoje.

Apdovanojimai: 1979 m. - Lietuvos kultūros ministerijos premija, 1985 m. - pirmasis Lietuvos kultūros ministerijos prizas 4-oje Baltijos šalių bienaleje, 1985 m. - pirmasis prizas 11-oje Baltijos šalių ir Islandijos bienalejje Rostoke (Vokietija), 1999 m. - Lietuvos dailininkų sąjungos premija, 2005 m. - M. J. Šileikio premija.

2012 m. išleistas albumas Jonas Daniliauskas. Tapyba. Sukurti 2 dokumentiniai filmai „Jonas Daniliauskas" (LTV, 1998 ir LDM, 2014).

\section{Painter Jonas Daniliauskas}

Born in 1950 in Lekéčiai, Šakiai district; studied at M.K. Čiurlionis School of Art; in 1974, graduated from the State Art Institute where he studied painting under A. Petrulis and J. Švažas (the latter was the supervisor of his diploma thesis). From 1974 till 1984, Daniliauskas taught painting at M.K. Čiurlionis School of Art and later at Vilnius Institute of Fine Arts. At the same time, he organized personal exhibitions in various Lithuanian cities, as well as in Baden, Zurich, Greifswald, London, Warsaw, Poznan, etc. Also he took part in collective exhibitions in Bulgaria, Denmark, Russia, Finland, USA, GDR, Germany, Poland, Latvia, Georgia, Turkey, Armenia, Japan, Spain, India, Great Britain, France, Switzerland, and Turkey.

Awards: 1979 - Prize of the Ministry of Culture of Lithuania, 1985 - first prize of the Lithuanian Ministry of Culture at the 4th Baltic Biennale, 1985- first prize at the 11th Baltic-Icelandic Biennale in Rostock (Germany), 1999 - Prize of the Lithuanian Artists' Union, 2005 - M. J. Šileikis Prize.

In 2012, the album "Jonas Daniliauskas. Painting" was printed and published. In 1998 and 2014 documentaries "Jonas Daniliauskas" were filmed.

RAKTAŽODŽIAI: Jonas Daniliauskas, tapyba.

KEY WORDS: Jonas Daniliauskas, painting. 


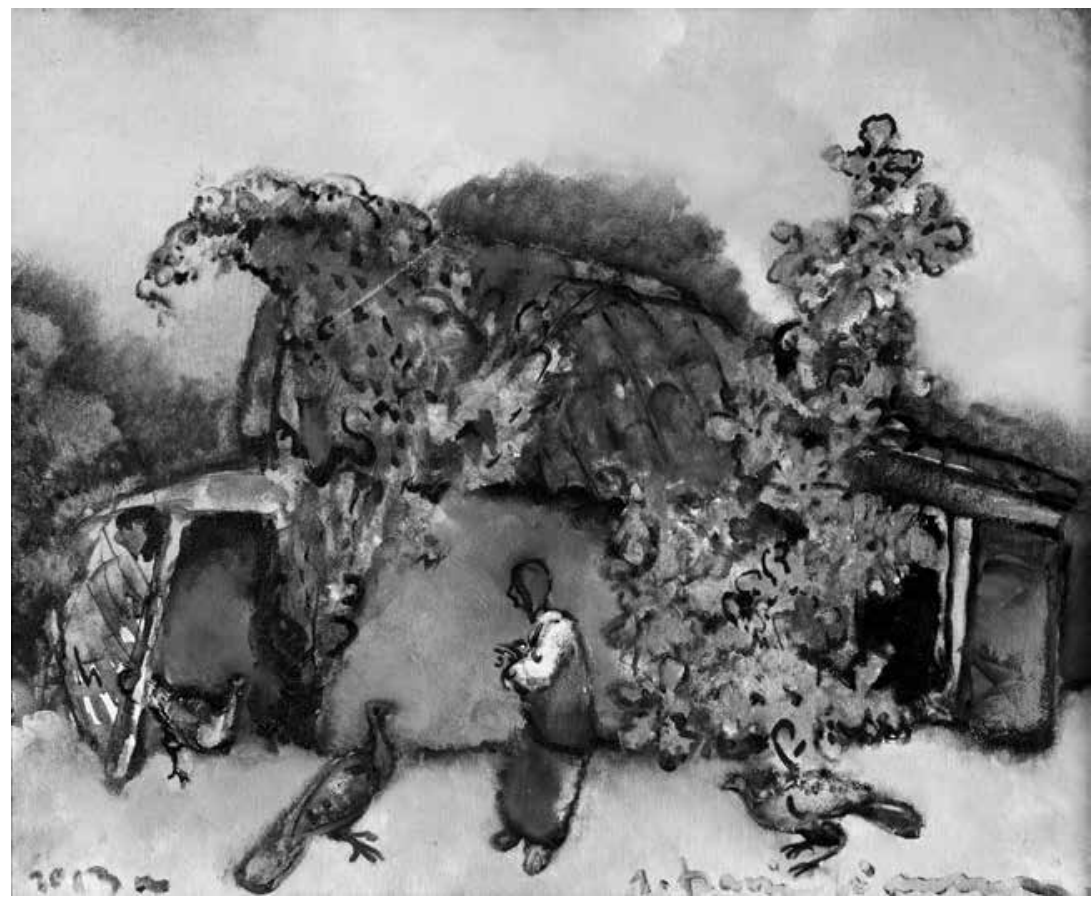

Jonas DANILIAUSKAS. Moteris su kalakutais, 2013, al., dr., 60 × 73

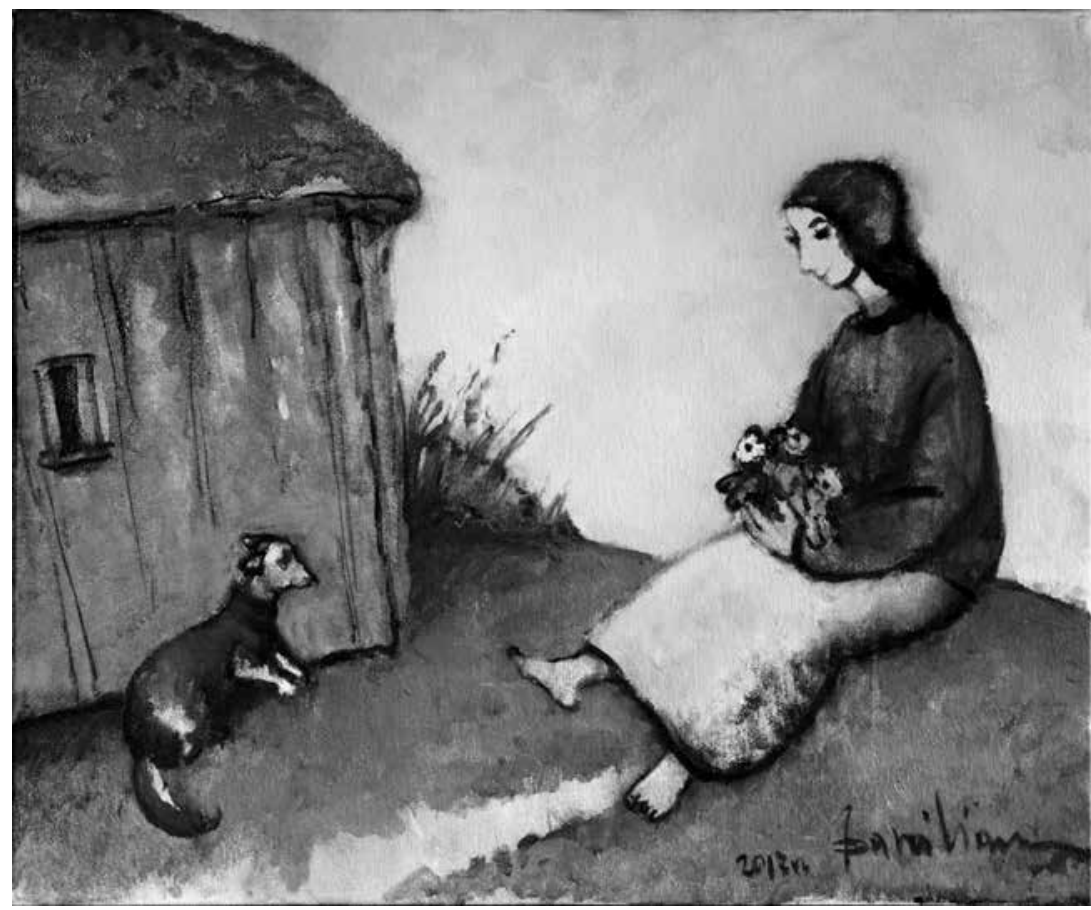

Jonas DANILIAUSKAS. Mergaitè su šuniukais, 2016-2017, al., dr., 50 × 61 


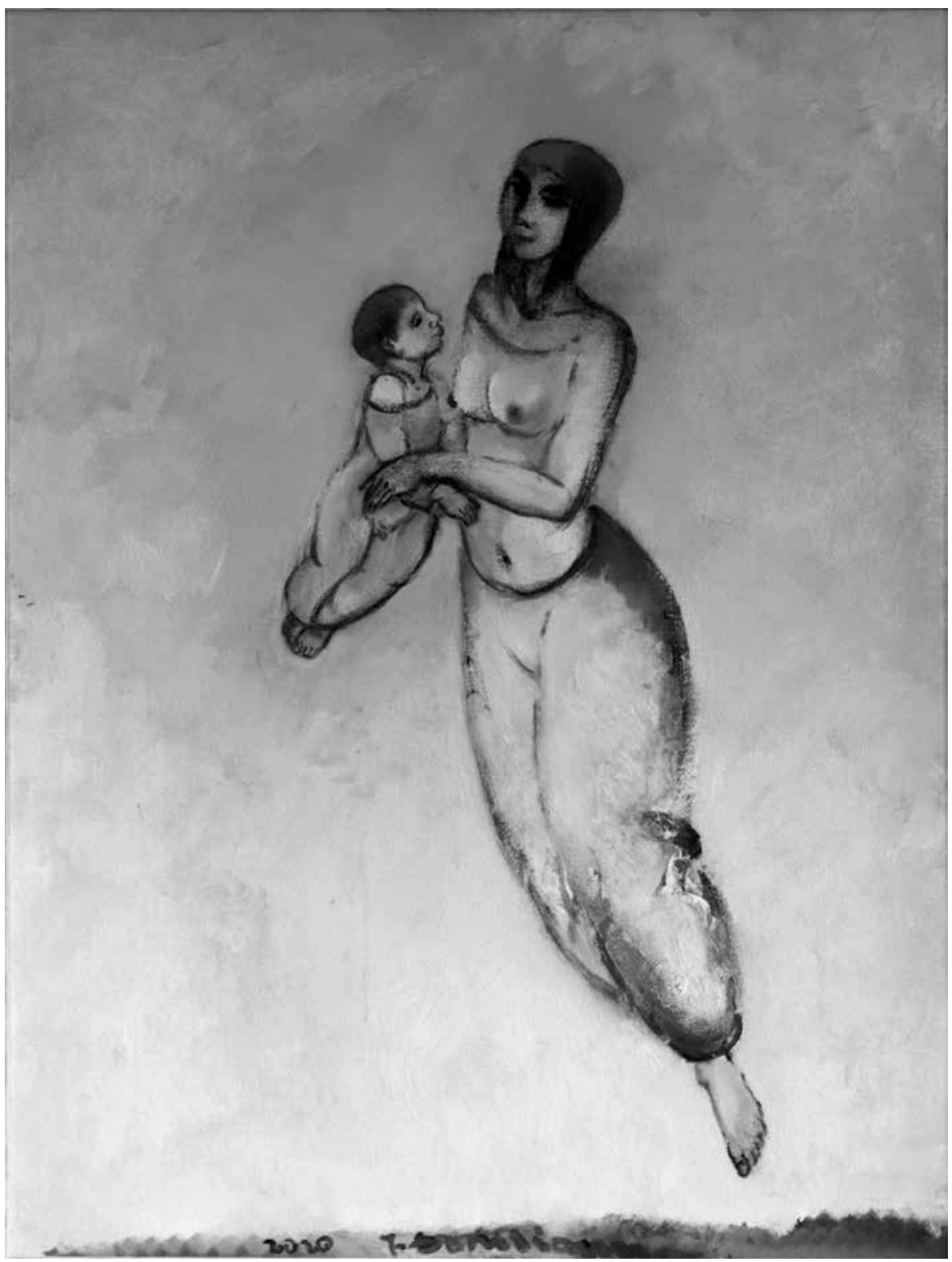

Jonas DANILIAUSKAS. Pašokusi virš vandens, 2018, al., dr., $92 \times 65$ 


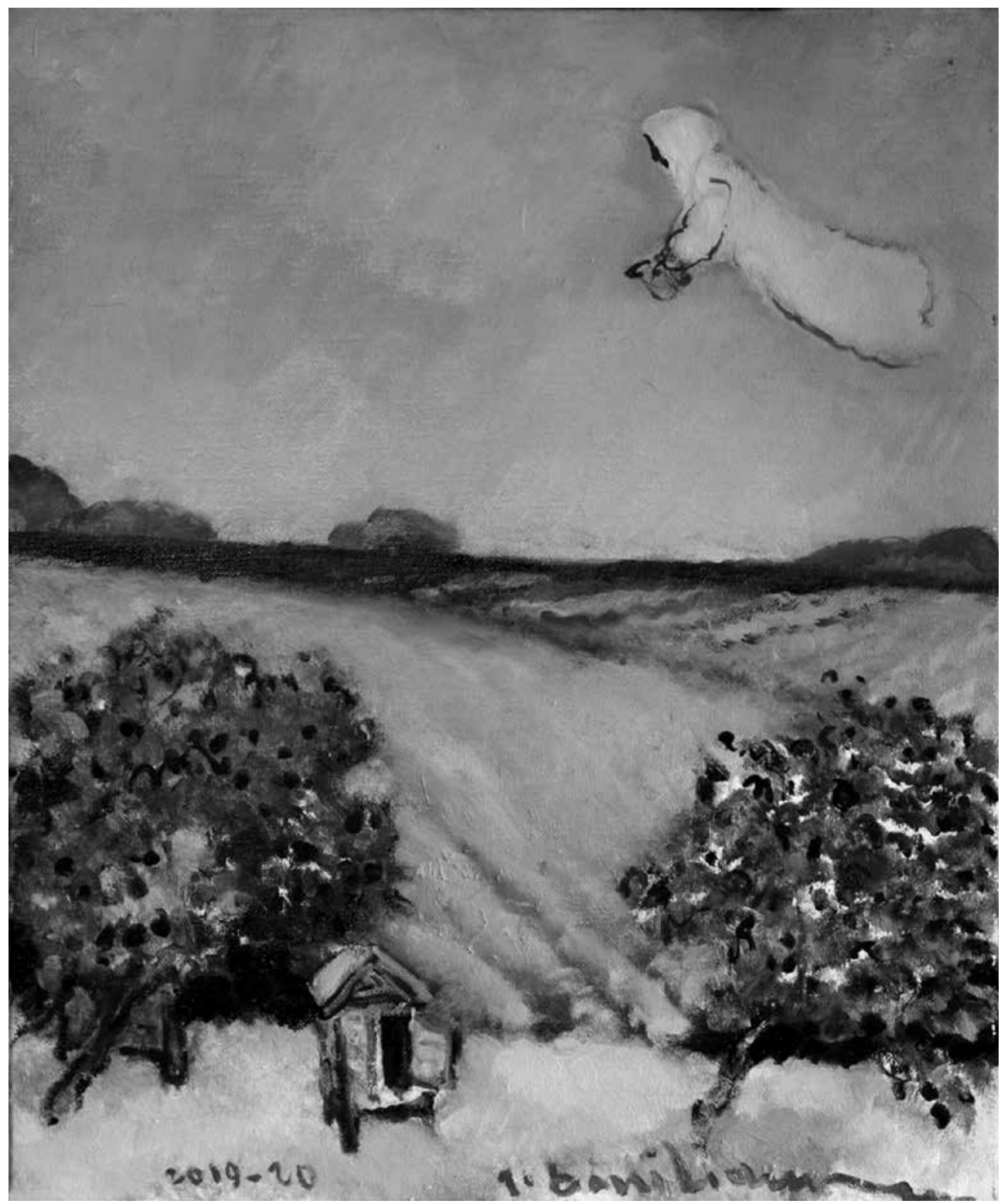

Jonas DANILIAUSKAS. Kaimo bitininko dvasia, 2019, al., dr., $73 \times 60$ 


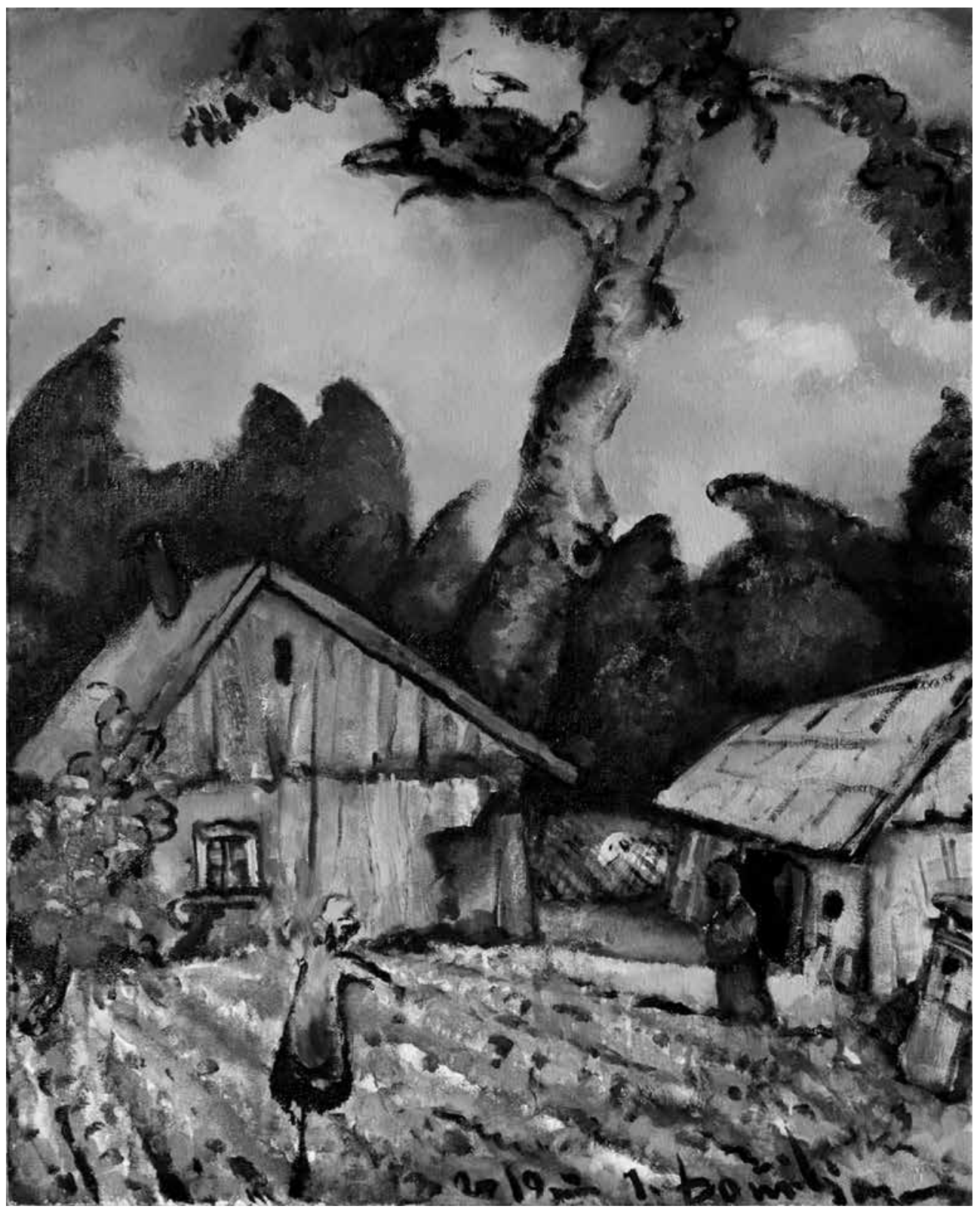

Jonas DANILIAUSKAS. Sodyba Luokejje, 2019, al., dr., 81 × 65 


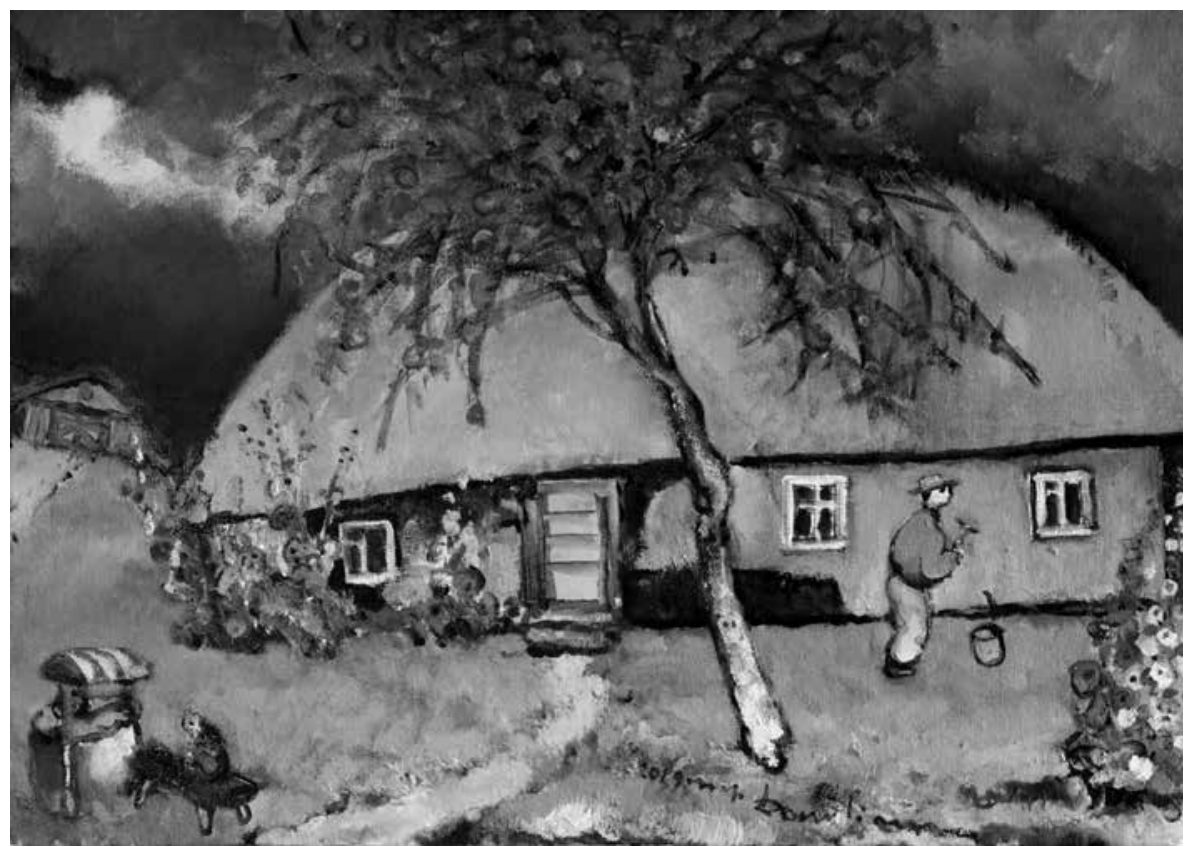

Jonas DANILIAUSKAS. Perdažomas namas Užventyje, 2019, al., dr., $65 \times 92$

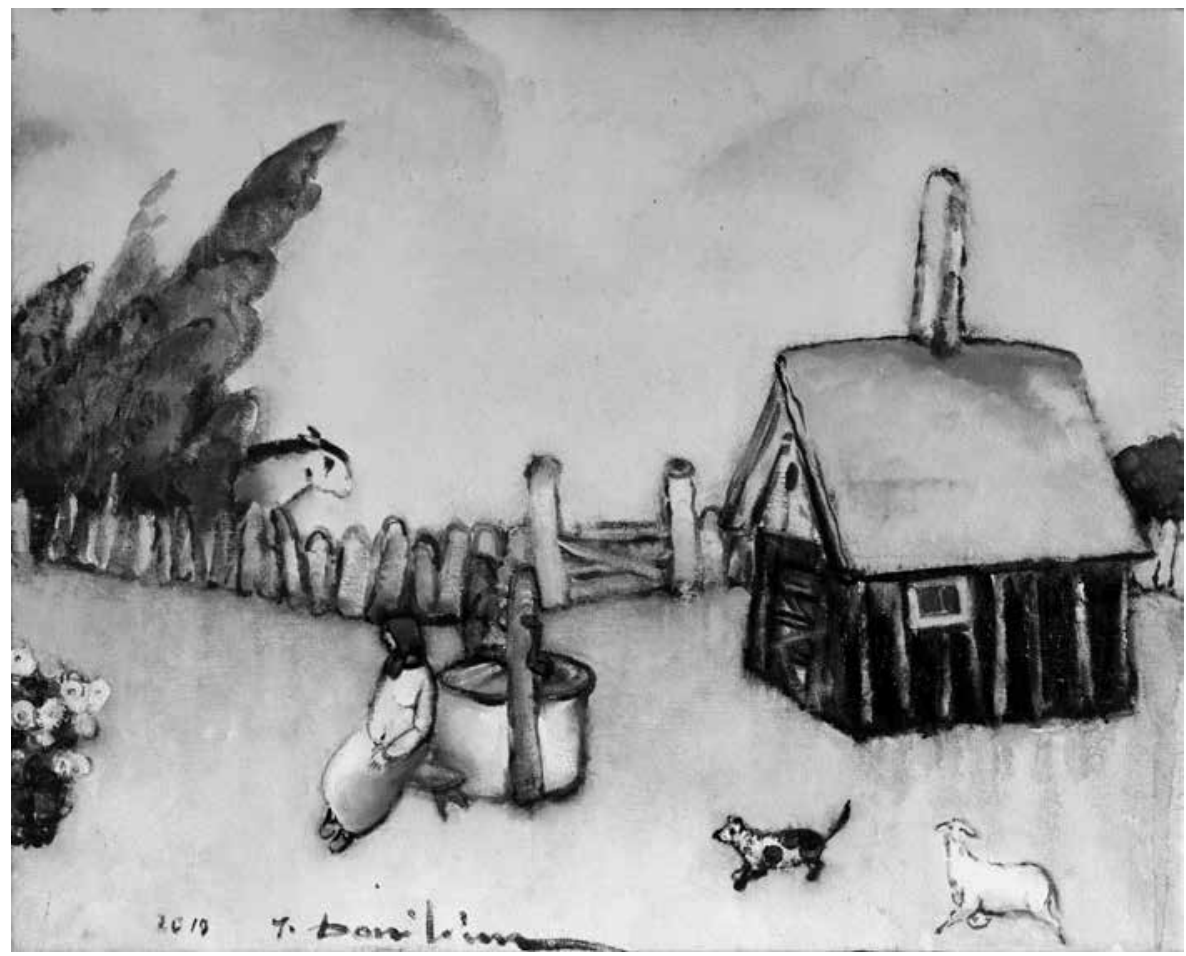

Jonas DANILIAUSKAS. Maža kiemo virtuvèlè, 2019, al., dr., 65 × 81 


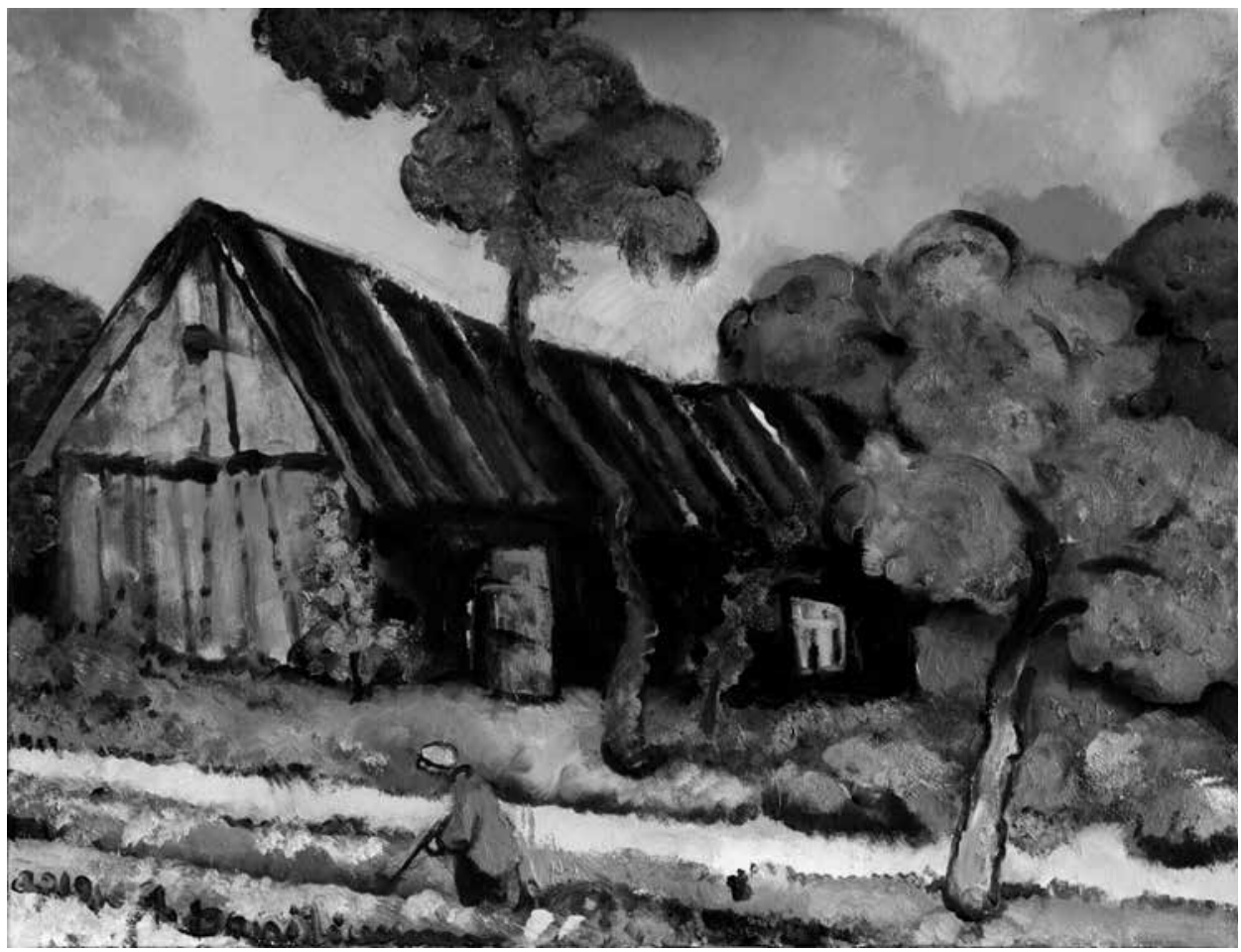

Jonas DANILIAUSKAS. Ravinti bulves, 2019, al., dr., $65 \times 92$

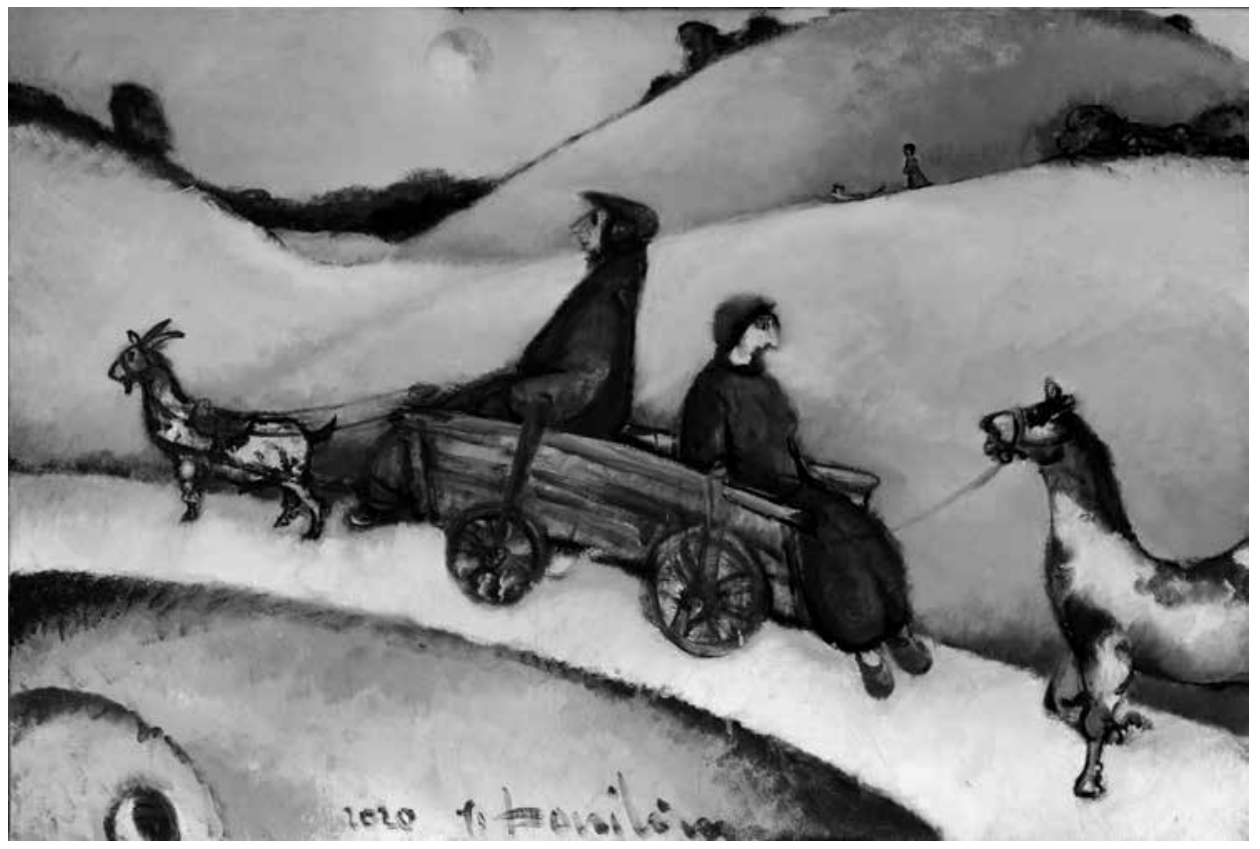

Jonas DANILIAUSKAS. Kaimo keistuolio šeima, 2019, al., dr., $80 \times 120$ 